\title{
Sunflower cake from biodiesel production fed to crossbred Boer kids ${ }^{1}$
}

\author{
Mariza Sufiana Faharodine Aly Agy $^{2}$, Ronaldo Lopes Oliveira ${ }^{3}$, Claudio Vaz Di Mambro \\ Ribeiro $^{3}$, Marinaldo Divino Ribeiro ${ }^{4}$, Adriana Regina Bagaldo ${ }^{5}$, Gherman Garcia Leal de \\ Araújo $^{6}$, Luís Fernando Batista Pinto ${ }^{3}$, Rebeca Dantas Xavier Ribeiro ${ }^{7}$
}

\footnotetext{
${ }^{1}$ Research funded by FAPESB.

2 Mestrando em Ciência Animal nos Trópicos/EMEV - UFBA. Scholar from CNPq.

${ }^{3}$ Departamento de Produção Animal - EMEVIUFBA. Researcher from CNPq.

${ }^{4}$ Departamento de Zootecnia e Extensão Rural - UFMG

${ }^{5}$ Centro de Ciências Agrárias Ambientais e Biológicas - UFRB.

${ }^{6}$ Embrapa Semiárido.

${ }^{7}$ Curso de graduação - Escola de Medicina Veterinária da UFBA, Salvador-BA.
}

ABSTRACT - The intake of the dry matter (DM), the crude protein (CP) and the metabolizable energy intake (ME) in megacalories per day (Mcal/day) were not affected by the diets. In contrast, the intake of neutral detergent fiber (NDF), in $\mathrm{g} / \mathrm{kg} \mathrm{BW}$, increased linearly. An increasing linear effect was also observed for the ether extract (EE) intake, whereas a decreasing linear performance was observed for the non-fibrous carbohydrate (NFC) intake. The digestibility of DM, organic matter and NFC decreased linearly with the sunflower cake inclusion, whereas the digestibility of CP, NDF, and EE were not influenced by the diets. No effect was observed for the concentration of serum glucose or urea nitrogen serum. No effect was observed on the urea nitrogen serum in the hours after feeding; however, including sunflower cake in the diets resulted in a quadratic performance for the serum glucose concentrations in the hours after feeding. The average daily gain (ADG) had a decreasing linear effect, and the food conversions of the DM, CP, NDF, NFC and ME had increasing linear effects. The feeding costs decreased with the level of sunflower cake.

Key Words: byproducts, digestibility, intake, performance, ruminants

\section{Introduction}

Goat farming in the Northeast of Brazil has an important socio-economic role and is mainly focused on meat and milk production. These products are an important nutritional and income source, especially for small producers (Simplício, 2003).

The Northeast of Brazil is home to $91 \%$ of the national goat population, and the state of Bahia has the largest national herd (IBGE, 2007). Although the number of animals is impressive, the breeding system adopted by the producers is predominantly extensive. In addition to this, producers are faced with limitations in obtaining feed for the animals that is rich in protein and energy, especially during the dry season, when the supply of forage is scarce, resulting in low animal performance (Dantas Filho, 2007).

To overcome this adversity, producers make use of concentrated feeds, which are expensive. Therefore, the byproducts of agroindustry have been investigated as an option to reduce the costs of animal feed (Alcade et al., 2009; Pires et al., 2009; Borja et al., 2010; Nunes et al., 2010).
Recent studies indicate that the byproducts from the biodiesel production have nutritional characteristics that render them suitable for the inclusion in the diet of ruminants (Abdalla et al., 2008; Correia et al., 2011; Ribeiro et al., 2011; Silva et al.; 2011; Sanders et al., 2011). Sunflower cake is a byproduct obtained after the extraction of the oil from the seeds (Domingues, 2006; Palmieri et al., 2011), and, according to Santos (2008), it presents values for crude protein above $22.9 \%$ and ether extract up to $6.75 \%$.

The present study was conducted to evaluate the inclusion of sunflower cake from the biodiesel production in the diet of crossbred Boer kids through the study of productive performance, apparent digestibility, blood parameters and feeding costs.

\section{Material and Methods}

The experiment was conducted in the Escola de Medicina Veterinária of the Universidade Federal da Bahia in Salvador, Bahia. Thirty-two uncastrated male crossbred Boer kids, aged 4.5 months ( \pm 15 days) and weighing 
Table 2 - Chemical composition of the ingredients in the diets fed to crossbred Boer kids

\begin{tabular}{|c|c|c|c|c|}
\hline \multirow[t]{2}{*}{ Item } & \multicolumn{4}{|c|}{ Ingredient } \\
\hline & Corn & Soybean meal & Sunflower cake & Tifton-85 hay (Cynodon sp. \\
\hline Dry matter (\%) & 88.57 & 89.17 & 91.85 & 86.81 \\
\hline Organic matter ${ }^{1}$ & 98.86 & 94.41 & 94.90 & 9.65 \\
\hline $\operatorname{Ash}^{1}$ & 1.14 & 5.59 & 5.10 & 7.35 \\
\hline Crude protein ${ }^{1}$ & 7.83 & 48.73 & 33.73 & 6.16 \\
\hline Ether extract ${ }^{1}$ & 4.11 & 1.93 & 6.85 & 1.12 \\
\hline Neutral detergent fiber ${ }^{1}$ & 10.91 & 10.17 & 32.23 & 79.52 \\
\hline Acid detergent fiber ${ }^{1}$ & 3.58 & 7.79 & 26.61 & 47.60 \\
\hline Hemicellulose ${ }^{1}$ & 7.33 & 2.38 & 5.62 & 31.91 \\
\hline Cellulose $^{1}$ & 2.72 & 7.16 & 19.56 & 38.19 \\
\hline $\operatorname{Lignin}^{1}$ & 0.82 & 0.63 & 7.05 & 9.41 \\
\hline Non-fibrous carbohydrates ${ }^{1}$ & 76.01 & 33.58 & 22.09 & 5.85 \\
\hline NDIN $(\% \text { total } \mathrm{N})^{2}$ & 10.36 & 3.84 & 9.11 & 39.18 \\
\hline ADIN $(\% \text { total } N)^{3}$ & 3.15 & 2.18 & 3.70 & 18.77 \\
\hline
\end{tabular}

$1 \%$ of the DM; ${ }^{2}$ Neutral detergent insoluble nitrogen; ${ }^{3}$ Acid detergent insoluble nitrogen.

Table 3 - Chemical composition of the experimental diets fed to crossbred Boer kids

\begin{tabular}{|c|c|c|c|c|}
\hline \multirow[t]{2}{*}{ Item } & \multicolumn{4}{|c|}{ Sunflower cake (DM \%) } \\
\hline & 0 & 8 & 16 & 24 \\
\hline Dry matter (\%) & 87.97 & 88.20 & 88.43 & 88.65 \\
\hline Organic matter ${ }^{1}$ & 93.41 & 93.32 & 93.53 & 93.18 \\
\hline $\operatorname{Ash}^{1}$ & 6.59 & 6.68 & 6.75 & 6.82 \\
\hline Crude protein $^{1}$ & 13.16 & 13.10 & 13.04 & 12.99 \\
\hline Ether extract ${ }^{1}$ & 2.21 & 2.54 & 2.87 & 3.19 \\
\hline Neutral detergent fiber ${ }^{1}$ & 44.92 & 46.65 & 48.37 & 50.08 \\
\hline Acid detergent fiber ${ }^{1}$ & 26.18 & 27.79 & 29.39 & 30.98 \\
\hline Hemicellulose ${ }^{1}$ & 18.73 & 18.86 & 18.98 & 19.09 \\
\hline $\operatorname{Lignin}^{1}$ & 5.07 & 5.58 & 6.08 & 6.57 \\
\hline Non-fibrous carbohydrates ${ }^{1}$ & 33.11 & 31.04 & 28.96 & 26.92 \\
\hline NDIN $(\% \text { total } \mathrm{N})^{2}$ & 23.61 & 23.83 & 24.06 & 24.30 \\
\hline ADIN $(\% \text { total } \mathrm{N})^{3}$ & 10.75 & 10.85 & 10.94 & 11.03 \\
\hline $\mathrm{ME}(\mathrm{Mcal} / \mathrm{kg})^{4}$ & 2.30 & 2.10 & 2.21 & 1.96 \\
\hline
\end{tabular}

$\mathrm{DM}=$ dry matter; $\mathrm{CV}$ = coefficient of variation.

$1 \%$ of DM.

2 Neutral detergent insoluble nitrogen.

3 Acid detergent insoluble nitrogen.

${ }^{4}$ Metabolizable energy.

market, at the time of the experiment, was R\$ 7.00. After obtaining the values of revenue and feeding costs, the calculation of the profitability (or gross margin) from the sale of the animals was found. The cost-benefit analysis was used to calculate the economic rate of return and to compare the carcass weight multiplied by the price of the carcass (in $\mathrm{kg}$ ) in relation to the amount spent on the feed. The break-even point (equilibrium) and the cost of the carcass per kilogram were determined as described by Hernandez Perez Junior et al. (2001).

The experiment was a completely randomized design with four treatments and eight repetitions. The data were submitted to an analysis of variance (GLM procedure, Statistical Analysis System, versão 9.1) and a regression test. The significance was defined at $\mathrm{P}<0.05$.

\section{Results and Discussion}

The dry matter intake was not influenced by the inclusion of the sunflower cake in the diets (Table 4), even with the increase in the neutral detergent fiber percentage in the diets (Table 3). It is likely that the size of the fiber fraction of sunflower cake, which was finely ground for subsequent mixing in the rations, promoted a normal transit in the digestive tract without causing ruminal-reticular filling. The inclusion of the sunflower cake in the diets did not promote changes in the crude protein intake (Table 4) because the diets were isonitrogenous and the dry matter intake was similar between the treatments. The average crude protein intake was $99 \mathrm{~g} /$ day, which is higher than the amount recommended by the NRC (2007).

The neutral detergent fiber intake, expressed in $/ \mathrm{kg} \mathrm{BW}$, increased linearly $(\mathrm{P}<0.05)$ with the inclusion of the sunflower cake in the diets (Table 4). Using sunflower cake in the diet of dairy cows, Santos (2008) observed no effect on the neutral detergent fiber or acid detergent fiber intake, which was also observed in the present study. The neutral detergent fiber intake, expressed in g/kg BW (Table 4), is consistent with the values cited by Van Soest (1994), who suggested an intake between 8.0 and $22.0 \mathrm{~g} / \mathrm{kg}$ BW for ruminants.

A linear decreasing effect on the non-fibrous carbohydrate intake was observed, with a reduction of $2.45 \mathrm{~g}$ for each percentage unit of sunflower cake added in the diet (Table 4). This result may be due to the reduction of the non-fibrous carbohydrate in the diets (Table 3 ). Such result was also observed by Silva (2006), when feeding lactating cows a diet that included babassu cake. The babassu cake has a high fiber content, which provides the least amount of non-fibrous carbohydrates, similar to sunflower cake (Silva, 2006). 
The ether extract intake showed a linear increase $(\mathrm{P}<0.05)$ due to the increase of this fraction with the inclusion of the sunflower cake in the diets (Table 3). However, the inclusion of the sunflower cake did not affect $(\mathrm{P}>0.05$ ) the metabolizable energy intake (Table 4 ), even with the decrease in the intake and digestibility of the non-fibrous carbohydrates (Tables 4 and 5). Possibly, the increased intake of ether extract components offset the reduction in the intake and digestibility of the non-fibrous carbohydrates.

The intake of water has a relationship with the amount of dry matter intake. In the present study, the water intake was not influenced by the addition of the sunflower cake in the diet due to the similarity in the dry matter intake (Table 4).

A linear effect $(\mathrm{P}<0.05)$ was observed for the dry matter and organic matter digestibility, with an estimated reduction of 0.306 and $0.308 \%$, respectively, per percentage unit of sunflower cake added in the diet (Table 5). This behavior can be attributed to the reduction of the digestibility of the non-fibrous carbohydrates. The linear decrease in the digestibility of the non-fibrous carbohydrates $(\mathrm{P}<0.05)$ with the inclusion of the sunflower cake (Table 5) probably occurred due to the increase in the levels of acid detergent fiber in the diet (Table 3), as the digestibility of the feed is more related to the content of the acid detergent fiber, and the fraction of indigestible fiber, lignin, represents a higher proportion in this component (Eastridge, 1997).

The inclusion of the sunflower cake in the diets did not change $(\mathrm{P}>0.05)$ the digestibility of the crude protein (Table 5). The mean of the digestibility obtained (80.6\%) was higher than the $72.5 \%$ reported by Santos et al. (2009) by feeding sheep rapeseed cake and the $58.0 \%$ observed by Silva et al. (2007) for diets containing palm kernel cake.

Table 4 - Dry matter (DM), crude protein, neutral detergent fiber, non-fibrous carbohydrates, ether extract, metabolizable energy and water intake by crossbred Boer kids fed diets containing sunflower cake

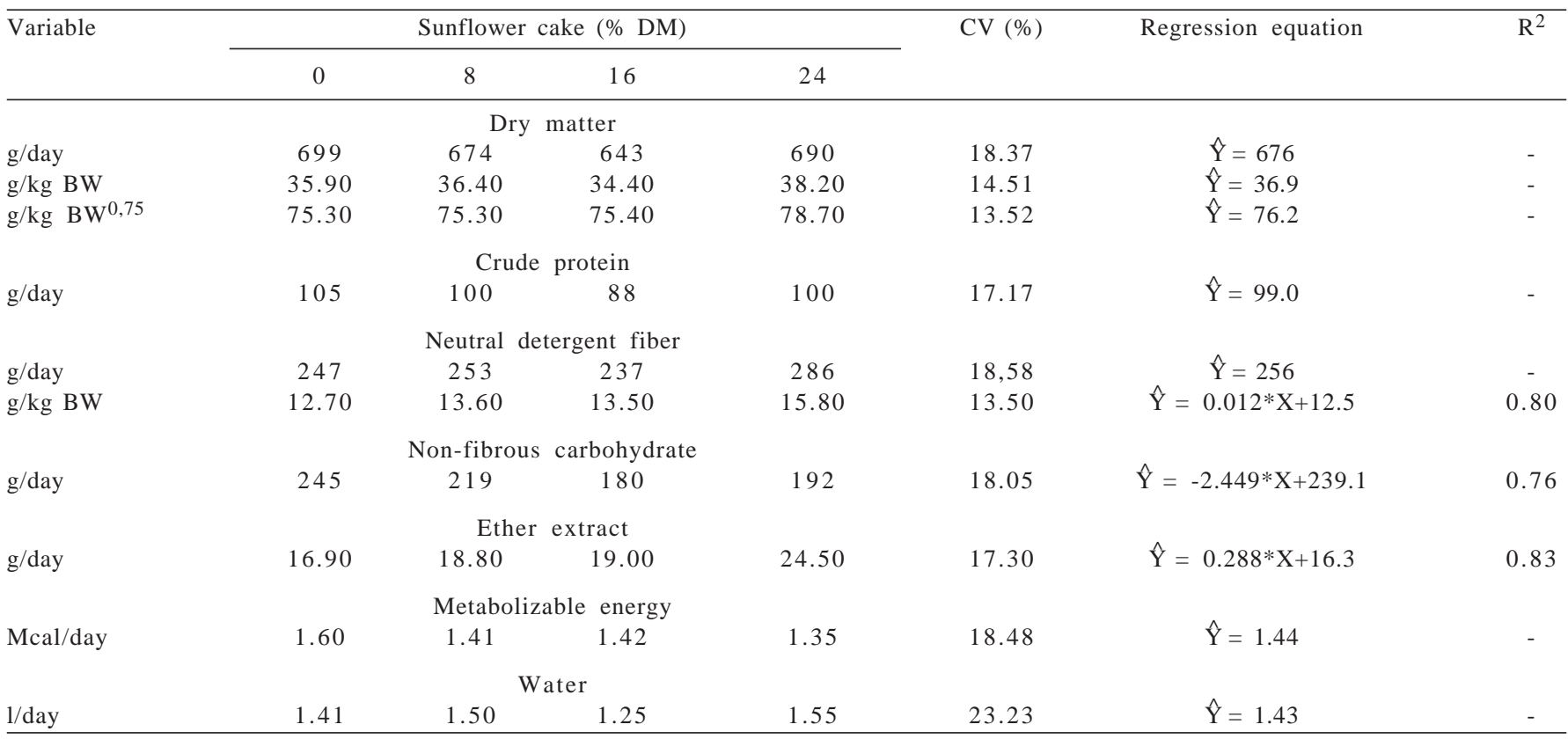

$\mathrm{CV}=$ coefficient of variation; $\mathrm{R}^{2}=$ coefficient of determination.

Table 5 - Effect of sunflower cake addition on the coefficients of digestibility of the dry matter (DM), organic matter (OM), non-fibrous carbohydrates (NFC), crude protein (CP), neutral detergent fiber (NDF), ether extract (EE) and metabolizable energy (ME)

\begin{tabular}{|c|c|c|c|c|c|c|c|}
\hline \multirow[t]{2}{*}{ Variable } & \multicolumn{4}{|c|}{ Sunflower cake (\% DM) } & \multirow[t]{2}{*}{ CV (\%) } & \multirow[t]{2}{*}{ Regression equation } & \multirow[t]{2}{*}{$\mathrm{R}^{2}$} \\
\hline & 0 & 8 & 16 & 24 & & & \\
\hline $\mathrm{DM}$ & 72.48 & 72.25 & 68.85 & 62.86 & 6.41 & $\hat{Y}=-0.306 * X+71.62$ & 0.61 \\
\hline OM & 74.52 & 68.57 & 72.36 & 65.03 & 5.75 & $\hat{Y}=-0.308 * X+73.82$ & 0.70 \\
\hline NFC & 86.73 & 84.58 & 83.94 & 75.70 & 5.53 & $\hat{Y}=-0.369 * X+86.14$ & 0.79 \\
\hline CP & 80.66 & 78.60 & 84.72 & 78.52 & 4.64 & $\hat{Y}=80.61$ & - \\
\hline NDF & 54.24 & 47.78 & 53.88 & 45.70 & 14.10 & $\hat{Y}=50.40$ & - \\
\hline $\mathrm{EE}$ & 84.18 & 84.04 & 87.72 & 84.26 & 5.43 & $\widehat{Y}=85.05$ & - \\
\hline ME (Mcal/kg) & 2.30 & 2.10 & 2.21 & 1.96 & 7.83 & $\hat{Y}=-0.112 * X+2.43$ & 0.64 \\
\hline
\end{tabular}

$\mathrm{CV}=$ coefficient of variation; $\mathrm{R}^{2}=$ coefficient of determination. 
The high digestibility of the crude protein in the sunflower cake was confirmed by Mupeta et al. (1997) when evaluating the quality of oilseed protein. The authors found that sunflower cake has a high ruminal degradability of crude protein and a high digestibility of rumen non-degradable protein.

In the current study, the levels of sunflower cake in the diets did not influence the digestibility of the neutral detergent fiber or ether extract (Table 5). The mean obtained for the neutral detergent fiber digestibility was lower than that observed by Santos et al. (2009) when evaluating diets containing rapeseed cake.

According to Silva (2004), sunflower cake fiber has low digestibility due to a higher lignin content because this fraction is a major factor limiting the digestion of cell wall polysaccharides. However, the neutral detergent fiber digestibility in the diet was $47.33 \%$, which is higher than that observed by Silva et al. (2005) in diets containing cocoa meal and palm kernel cake.

There was no change in the blood urea nitrogen (BUN) concentration between the hours of post-prandial blood collection. Averages of 23.5, 24.8, 25.3 and $24.9 \mathrm{mg} / \mathrm{dL}$ were obtained for 0, 2, 4 and 6 hours, respectively. Similar behavior was observed for the concentration of BUN in the different levels of sunflower cake (Table 6), probably because the crude protein intake (g/day) was similar between the treatments (Table 4), as the protein intake has a direct influence on the concentration of BUN. Furthermore, according to Baker et al. (1995), the energy intake also influences the concentration of BUN, and, in our study, the intake of metabolizable energy (Mcal/day) also did not change between the treatments. The concentration of BUN was close to the normal parameters observed for goats, which are between 10 to 20 mg/dL (Pugh \& Dum, 2005).
There was no effect of the inclusion of the sunflower cake on the blood glucose concentration (Table 6). However, there was a quadratic effect $(\mathrm{P}<0.05)$ between the hours of blood collection (Figure 1).

According to Pugh \& Dum (2005), the blood glucose concentration of goats ranges from 50 to $75 \mathrm{mg} / \mathrm{dL}$, thus, the results observed in our experiment are within the normal range (Table 6). The quadratic trend of the postprandial blood glucose was expected, considering that the concentration of glucose in the plasma is related to the hours after feeding. The peak observed was $61 \mathrm{mg} / \mathrm{dL}$ at 3.85 hours post-meal.

The inclusion of the sunflower cake in the diets reduced $(\mathrm{P}<0.05)$ the average daily gain (Figure 2 ). The regression equation obtained indicates a reduction of $0.002 \mathrm{~kg}$ for each increase of $1 \%$ of sunflower cake in the diets (Figure 2).

Although a similar metabolizable energy intake in relation to the inclusion levels of the sunflower cake (Table 4) was observed, the reduction in the average daily gain of the kids was probably due to the reduced nonfibrous carbohydrate intake and digestibility. The observed values of the average daily weight gain were $0.142,0.117$, 0.086 and $0.092 \mathrm{~kg}$ for the inclusion levels of $0.0,8.0,16.0$ and $24 \%$, respectively, and are close to the expected values of $0.100 \mathrm{~kg} / \mathrm{animal} /$ day.

Similarly, the reduction of the non-fibrous carbohydrate digestibility (Table 5) reflected in worsening of the feed conversion; therefore, the conversion of the dietary dry matter, crude protein, neutral detergent fiber, non-fiber carbohydrates and total digestible nutrients showed linear increase $(\mathrm{P}<0.05)$ with the inclusion of the sunflower cake in the diets (Table 7). According to Cardoso et al. (2006), linear reductions in the daily gain and feed conversion

Table 6 - Concentration of blood urea nitrogen (BUN) and blood glucose (mg/dL) in crossbred Boer kids fed diets containing sunflower cake

\begin{tabular}{lccccccc}
\hline Variable (mg/dL) & \multicolumn{4}{c}{ Sunflower cake (DM \%) } & \multirow{2}{*}{ CV (\%) } & Regression equation & \\
\cline { 2 - 5 } & 0 & 8 & 16 & 24 & & \\
\hline BUN & 26.68 & 25.81 & 22.67 & 23.37 & 19.68 & $\hat{Y}=24.63$ & - \\
Glucose & 58.68 & 59.26 & 55.70 & 55.47 & 12.84 & $\hat{Y}=57.28$ & - \\
\hline
\end{tabular}

$\mathrm{CV}$ = coefficient of variation; $\mathrm{R}^{2}=$ coefficient of determination.

Table 7 - Feed conversion of the dry matter (DM), crude protein (CP), neutral detergent fiber (NDF), non-fibrous carbohydrates (NFC) and total digestible nutrients (TDN) in crossbred Boer kids fed diets containing sunflower cake

\begin{tabular}{|c|c|c|c|c|c|c|c|}
\hline \multirow[t]{2}{*}{ Feed conversion } & \multicolumn{4}{|c|}{ Sunflower cake (\% DM) } & \multirow[t]{2}{*}{ CV (\%) } & \multirow[t]{2}{*}{ Regression equation } & \multirow[t]{2}{*}{$\mathrm{R}^{2}$} \\
\hline & 0 & 8 & 16 & 24 & & & \\
\hline $\mathrm{DM}^{1}$ & 5.36 & 5.87 & 7.75 & 7.58 & 18.06 & $\hat{Y}=0.107 * X+5.372$ & 0.83 \\
\hline $\mathrm{CP}^{1}$ & 0.81 & 0.83 & 1.08 & 1.11 & 19.53 & $\hat{Y}=0.014 * X+0.806$ & 0.90 \\
\hline $\mathrm{NDF}^{1}$ & 1.88 & 2.21 & 2.88 & 3.14 & 18.75 & $\hat{Y}=0.056 * X+1.863$ & 0.97 \\
\hline $\mathrm{NFC}^{1}$ & 1.89 & 1.91 & 2.19 & 2.11 & 19.57 & $\hat{Y}=0.012 * X+1.888$ & 0.66 \\
\hline $\mathrm{TDN}^{1}$ & 3.44 & 3.43 & 4.79 & 4.15 & 18.42 & $\hat{Y}=0.044 * X+3.435$ & 0.48 \\
\hline
\end{tabular}

${ }^{*} \mathrm{P}<0.05 ;{ }^{1} \mathrm{~kg} / \mathrm{kg}$ of gain; $\mathrm{CV}=$ coefficient of variation; $\mathrm{R}^{2}=$ coefficient of determination. 
efficiency are due to the reduction of digestible nutrients.

In the economic evaluation, the cost of feed per animal per day was lower in the group fed a diet with $24 \%$ sunflower cake (Table 9) because there was less inclusion of corn and soybeans (Table 8). Positive values of the gross margin for all of the treatments were observed (Table 9), and the inclusion level of $8 \%$ sunflower cake had the highest gross margin.

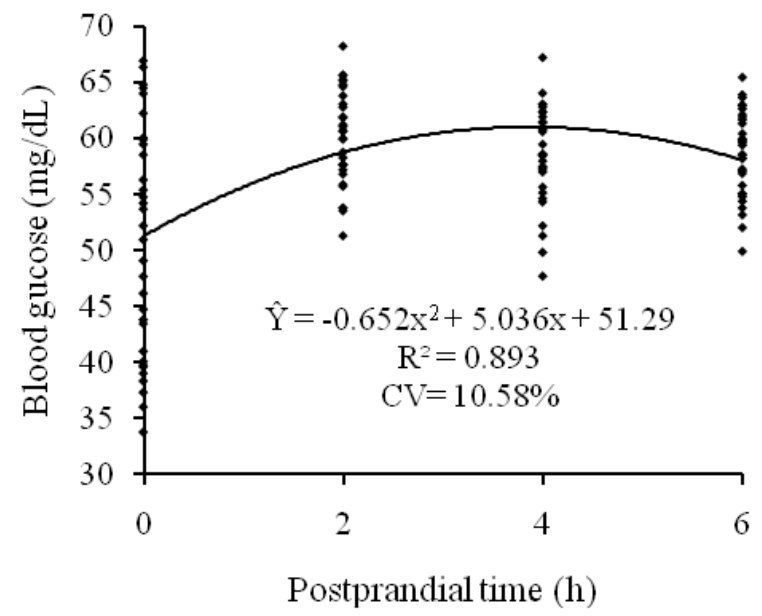

Figure 1 - Blood glucose concentration in crossbred Boer kids fed diets containing sunflower cake.

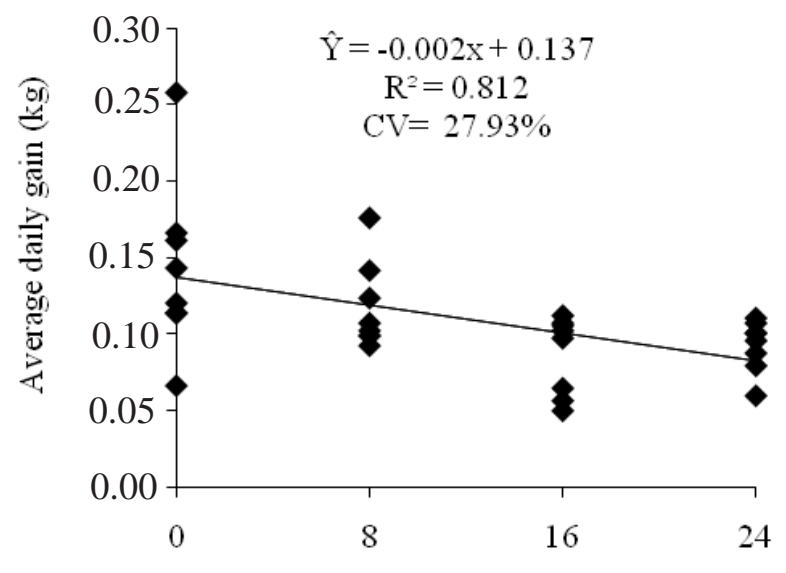

Sunflower cake (DM\%)

Figure 2 - Average daily gain of crossbred Boer kids fed diets containing sunflower cake.
The cost-benefit analysis was positive in all of the treatments, and the treatment with the inclusion of $8 \%$ sunflower cake had a better return, with R $\$ 1.63$ for each R\$ 1.00 of the total cost of diets (Table 9). Therefore, the inclusion of $8 \%$ sunflower cake in the diet resulted in a better cost-benefit and offers the best option of profitability. By the measure of the cost per $\mathrm{kg}$ of carcass produced, the level of an $8 \%$ inclusion of sunflower cake in the diet seems to be the most competitive (Table 9). Another financial indicator is the break-even point, which represents the amount of product sales required to cover the total cost. In the present study, this value was $5.40 \mathrm{~kg}$ of carcass, observed for the inclusion level of 24\% (Table 9), which indicates that the minimum productivity should be $5.40 \mathrm{~kg}$ of carcass per animal, which does not cause injuries. From this point of view, the $24 \%$ sunflower cake treatment becomes profitable, which was observed for the other treatments.

Table 8 - Feeding costs of the diets containing sunflower cake

\begin{tabular}{lccccc}
\hline Item & $\begin{array}{c}\text { Cost } \\
\text { (R\$) }\end{array}$ & \multicolumn{4}{c}{ Sunflower cake (DM \%) } \\
\cline { 3 - 6 } & & 0 & 8 & 16 & 24 \\
\hline Corn & 0.59 & 0.19 & 0.18 & 0.16 & 0.15 \\
Soybean meal & 0.92 & 0.15 & 0.09 & 0.05 & 0.00 \\
Sunflower cake & 0.45 & 0.00 & 0.03 & 0.07 & 0.10 \\
Minerals & 3.00 & 0.05 & 0.05 & 0.04 & 0.04 \\
Tifton-85 hay (Cynodon sp.) & 0.65 & 0.34 & 0.33 & 0.33 & 0.33 \\
Cost per animal/day (R\$) & - & 0.73 & 0.68 & 0.65 & 0.62 \\
\hline
\end{tabular}

DM = dry matter.

Table 9 - Economic evaluation of the feeding costs of the diets containing sunflower cake

\begin{tabular}{|c|c|c|c|c|}
\hline \multirow[t]{2}{*}{ Item } & \multicolumn{4}{|c|}{ Sunflower cake (DM \%) } \\
\hline & 0 & 8 & 16 & 24 \\
\hline Feed cost/animal/day $(\mathrm{R} \$)^{1}$ & 0.73 & 0.68 & 0.65 & 0.62 \\
\hline Days in feedlot & 61 & 61 & 61 & 61 \\
\hline Total feed cost & 44.53 & 41.48 & 39.65 & 37.82 \\
\hline Initial body weight (kg) & 15.05 & 15.40 & 15.13 & 15.80 \\
\hline Final body weight (kg) & 23.72 & 22.53 & 20.40 & 21.21 \\
\hline Average daily gain $(\mathrm{kg})$ & 0.142 & 0.117 & 0.086 & 0.092 \\
\hline Average gain (kg) & 8.675 & 7.137 & 5.262 & 5.612 \\
\hline Total revenue $(\mathrm{R} \$)^{1}$ & 64.75 & 67.83 & 57.12 & 60.20 \\
\hline Gross margin $(\mathrm{R} \$)^{2}$ & 20.22 & 26.35 & 17.47 & 22.38 \\
\hline Benefit/cost ${ }^{3}$ & 1.45 & 1.63 & 1.44 & 1.59 \\
\hline Cold carcass yield (\%) & 39.18 & 43.21 & 39.65 & 40.02 \\
\hline Meat price $(\mathrm{R} \$ / \mathrm{kg})$ & 7.00 & 7.00 & 7.00 & 7.00 \\
\hline Cold carcass weight ( $\mathrm{kg} / \mathrm{animal})$ & 9.25 & 9.69 & 8.16 & 8.60 \\
\hline Break-even point $(\mathrm{kg})^{4}$ & 6.36 & 5.92 & 5.66 & 5.40 \\
\hline Cost $(\mathrm{R} \$) / \mathrm{kg}$ of carcass $^{5}$ & 4.81 & 4.28 & 4.85 & 4.39 \\
\hline
\end{tabular}

$\mathrm{DM}=$ dry matter.

${ }^{1}$ Mean price per animal.

2 Total income (R\$) - total cost (R\$).

3 Total income $(\mathrm{R} \$) \div$ total cost $(\mathrm{R} \$)$

4 Total cost $(\mathrm{R} \$) \div$ meat price $\mathrm{kg}(\mathrm{R} \$)$.

5 Total cost $(\mathrm{R} \$) \div$ cold carcass weight $(\mathrm{kg})$. 


\section{Conclusions}

The inclusion of sunflower cake in the diets resulted in an increase of the neutral detergent fiber and a reduction of the non-fibrous carbohydrates, which had a negative influence on the growth performance of the animals. However, sunflower cake can be added up to $8 \%$ in the diets of crossbred Boer kids, as the expected production level performance and a better gross margin was achieved.

\section{References}

ABDALLA, A.L.; SILVA FILHO, J.C.; GODOI, A.R. et al. Utilização de subprodutos da indústria de biodiesel na alimentação de ruminantes. Revista Brasileira de Zootecnia, v.37, p.260-268, 2008.

ALCALDE, C.R.; ZAMBOM, M.A.; PASSIANOTO, G.O. et al. Valor nutritivo de rações contendo casca do grão de soja em substituição ao milho moído para cabritos Saanen. Revista Brasileira de Zootecnia, v.38, n.11, p.2198-2203, 2009.

ASSOCIATION OF ANALYTICAL CHEMISTS - AOAC. Official methods of analysis. 12.ed. Washington, D.C., 1990. 1094p.

BAKER, L.D.; FERGUSON, J.D.; CHALUPA, W. Reponses in urea and true protein of milk to different protein feeding schemes for dairy cows. Journal of Dairy Science, v.78, n.1995, p.2424-2434, 1995

BORJA, M.S.; OLIVEIRA, R.L.; RIBEIRO, C.V.D.M. et al. Effects of feeding licury (Syagrus coronate) cake to growing goats. Asian-Australasian Journal of Animal Sciences, v.23, p.1436-1444, 2010.

CARDOSO, A.R.; PIRES, C.C.; CARVALHO, S. et al. Consumo de nutrientes e desempenho de cordeiros alimentados com dietas que contêm diferentes níveis de fibra em detergente neutro. Ciência Rural, v.36, p.217-220, 2006.

CORREIA, B.R.; OLIVEIRA, R.L.; JAEGER, S.M.P.L. et al. Consumo, digestibilidade e $\mathrm{pH}$ ruminal de novilhos submetidos a dietas com tortas oriundas da produção do biodiesel em substituição ao farelo de soja. Arquivo Brasileiro de Medicina Veterinária e Zootecnia, v.63, p.356-363, 2011.

DANTAS FILHO, L.A.; LOPES, J.B.; VASCONCELOS, V.R. et al. Inclusão de polpa de caju desidratada na alimentação de ovinos: desempenho, digestibilidade e balanço de nitrogênio. Revista Brasileira de Zootecnia, v.36, n.1, p.147-154, 2007.

DOMINGUES, A.R. Consumo de matéria seca, parâmetros ruminais e sanguíneo de bovinos de corte em resposta a níveis de torta de girassol em substituição ao farelo de algodão. 2006. 48f. Dissertação (Mestrado em Ciência Animal) Centro de Ciências Agrárias/Universidade Estadual de Londrina.

EASTRIDGE, M.L. Fibra para vacas leiteiras. In: SIMPÓSIO SOBRE PRODUÇÃOANIMAL, 9., 1997, Piracicaba. Anais... Piracicaba: Fundação de Estudos Agrários “Luiz de Queiroz”, 1997. p.33-50.

HERNANDEZ PEREZ JUNIOR, J.; OLIVEIRA, L.M.; COSTA, R.G. Gestão estratégica de custos. 2.ed. São Paulo: Atlas, 2001. $216 p$.

INSTITUTO BRASILEIRO DE GEOGRAFIA E ESTATÍSTICAS IBGE. 2007. Sistema IBGE de recuperação automática. Disponível em: <http:// www.sidra.ibge.gov.br> Acesso em: 1 out. 2007

MUPETA, B.; WEISBJERG, M.R.; HVELPLUND, T. et al. Digestibility of amino acids in protein rich tropical feeds for ruminants estimated with the mobile bag technique. Animal Feed Science and Technology, v.69, n.1, p.271-280, 1997.
NATIONAL RESEARCH COUNCIL - NRC. Nutrient requirements of small ruminant. Washington, D.C.: National Academy Press, 2007. 282p.

NATIONAL RESEARCH COUNCIL - NRC. Nutrient requirements of dairy cattle. 7.ed. Washington, D.C.: National Academy Press, 2001. 251p.

NUNES, A.S.; OLIVEIRA, R.L.; AYRES, M.C.C. et al. Condição hepática de cordeiros mantidos com dietas contendo torta de dendê proveniente da produção de biodiesel. Revista Brasileira de Zootecnia, v.39, p.1825-1831, 2010.

PALMIERI, A.D.; OLIVEIRA, R.L.; RIBEIRO, C.V.D.M. et al. Effects of substituting soybean meal for sunflower cake in the diet on the growth and carcass traits of crossbred Boer goat kids. AsianAustralasian Journal of Animal Sciences, 2011 (in press).

PIRES, A.J.V.; CARVALHO, G.G.P.; GARCIA, R. et al. Fracionamento de carboidratos e proteínas de silagens de capimelefante com casca de café, farelo de cacau ou farelo de mandioca. Revista Brasileira de Zootecnia, v.38, n.3, p.422-427, 2009.

PUGH, D.C.; DUM, M.S. Clínica de ovinos e caprinos. São Paulo: Edições Roca, 2005. 1150p.

RIBEIRO, R.D.X. ; OLIVEIRA, R.L.; MACOME, F.M. et al. Meat quality of lambs fed on palm Kernel meal, a byproduct of biodiesel production. Asian-Australasian Journal of Animal Sciences, v.24, p.1399-1406, 2011.

SANDERS, D.M.; OLIVEIRA, R.L.; MOREIRA, E.L.T. et al. Morfometria da mucosa ruminal de cordeiros Santa Inês alimentados com níveis de torta de dendê (Elaeis guineensis), oriunda da produção do biodiesel. Semina.Ciências Agrárias, v.32, p.1169-1178, 2011.

SANTOS, J. Derivados da extração do óleo de girassol para vacas leiteiras. 2008. 8f. Tese (Doutorado em Zootecnia) Faculdade de Ciências Agrárias e Veterinárias do Campus de Jaboticabal/Universidade Estadual Paulista, Jaboticabal.

SANTOS, V.C.; EZEQUIEL, J.M.B.; OLIVEIRA, P.S.N. et al. Consumo e digestibilidade em ovinos alimentados com grãos e subprodutos da canola. Revista Brasileira de Saúde e Produção Animal, v.10, n.1, p.96-105, 2009.

SILVA, H.G.O.; PIRES, A.J.V.; SILVA, F.F. et al. Farelo de cacau (Theobroma cacao L.) e torta de dendê (Elaeis guineensis, Jacq) na alimentação de cabras em lactação: consumo e produção de leite. Revista Brasileira de Zootecnia, v.34, n.5, p.1790-1798, 2005.

SILVA, H.G.O.; PIRES, A.J.V.; CUNHA NETO, P.A. et al. Digestibilidade de dietas contendo silagem de capim-elefante amonizado e farelo de cacau ou torta de dendê em ovinos. Revista Brasileira de Zootecnia, v.36, n.2, p.499-506, 2007.

SILVA, T.M.; OLIVEIRA, R.L.; BARBOSA, L.P. et al. Preliminary study on meat quality of goats fed levels of licury oil in the diet. Asian-Australasian Journal of Animal Sciences, v.24, p.1112-1119, 2011.

SILVA, T.C.P. Substituição do farelo de trigo pela torta de babaçu na alimentação de vacas mestiças em lactação. 2006. 30f. Dissertação (Mestrado em Zootecnia) - Universidade Federal Rural de Pernambuco, Recife.

SILVA, Z.F. Torta de girassol na alimentação de vacas em lactação. 2004. 36f. Dissertação (Mestrado em Zootecnia) Faculdade de Ciências Agrárias e Veterinárias do Campus de Jaboticabal, Universidade Estadual Paulista, Jaboticabal.

SIMPLÍCIO, A.A.; WANDER, A.E.; LOPES, E.A. A caprinoovinocultura de corte como alternativa para a geração de emprego e renda. Sobral: Embrapa Caprinos, 2003. 17p. (Documentos, 48).

SNIFFEN, C.J.; O’CONNOR, J.D.; VAN SOEST, P.J. et al. A net carbohydrate and protein system for evaluation cattle diets. II Carbohydrate and protein availability. Journal of Animal Science, v.70, n.11, p.3562-3577, 1992.

VAN SOEST, P.J.; ROBERTSON, J.B.; LEWIS, B.A. Methods for dietary fiber, neutral detergent fiber, and nonstarch 
polyssacharides in relation to animal nutrition. Journal of Dairy Science, v.74, n.10, p.3583-3597, 1991.

VAN SOEST, P.J. Nutritional ecology of the ruminant. 2.ed. New York: Cornell University Press, 1994. 476p.
WEISS, W.P. Energy prediction equations for ruminant feeds. In: CORNELL NUTRITION CONFERENCE FOR FEED MANUFACTURERS, 61., 1999, Ithaca. Proceedings... Ithaca: Cornell University, 1999. p.176-185. 